\title{
Why Why Darwin Matters Matters
}

\author{
Why Darwin Matters: The Case Against Intelligent Design, by Michael Shermer. \\ New York: Henry Holt, 2006. Pp. xxii +199 . S/b \$14.00
}

\author{
Tania Lombrozo
}

Published online: 19 December 2008

(C) The Author(s) 2008. This article is published with open access at Springerlink.com

The first decade of the twenty-first century will be a curious chapter in the future history of evolutionary thought. In 2005, resistance to evolution manifested in the highly publicized trial of Dover, Pennsylvania over teaching Intelligent Design in public schools. Only four years later, in 2009, universities, museums, and individuals across the globe celebrate the 150th anniversary of the publication of Darwin's Origin of Species. Released in the interlude, Michael Shermer's Why Darwin Matters: The Case Against Intelligent Design takes on the challenge these landmark dates represent: how a thoroughly vetted and accepted scientific theory can be the source of so much cultural conflict. Shermer considers the sources of resistance to evolution, what is at stake, and what a reconciliation between science and religion might look like.

Shermer's own experiences and expertise make him uniquely suited to the task of explaining the overwhelming evidence for evolution...and why it is under attack. Like Darwin, Shermer was a creationist before he was an evolutionist. An evangelical Christian for seven years, he rejected evolution and even considered theology as a profession. But like Darwin, he pursued science instead of theology and followed in Darwin's footsteps as far as the Galapagos Islands, visiting 169 years after Darwin's crucial visit.

Why Darwin Matters begins with an explanation of evolution and the overwhelming evidence for natural selection. Shermer skillfully interweaves themes from history and philosophy of science in his exposition of the science, yielding

\section{T. Lombrozo $(\bowtie)$}

Department of Psychology, University of California,

3210 Tolman Hall,

Berkeley, CA 94720, USA

e-mail: lombrozo@berkeley.edu a brief but lucid overview of key evolutionary ideas. He emphasizes that the source of resistance to evolution is rarely the scientific details but rather the perceived consequences of evolution: atheism, ethical nihilism, and a lack of meaning. What people care about "is whether teaching evolution will make their kids reject God, allow criminals and sinners to blame their genes for their actions, and generally cause society to fall apart" (p. 25). But according to Shermer, an even greater threat to the theory of evolution is misunderstanding. A large proportion of the public not only misunderstands evolutionary theory but also aspects of science and the scientific process-for example, that calling evolution a "theory" is not a mark against its evidential standing.

The real case against Intelligent Design comes in Chapter 4 ("Debating Intelligent Design"), where Shermer identifies common fallacies that underlie challenges to evolution and considers the ten best arguments for an intelligent designer. The arguments range from classics like the argument from design to those that attempt to bolster Intelligent Design's scientific credibility: Behe's (1996) “irreducible complexity," Dembski's (2002) Law of Conservation of Information, and Wells's (2000) challenge to the icons of evolution. Shermer provides a clear statement of each argument along with a rebuttal.

In the end, Shermer is not impressed. He closes the chapter with this summary of what Intelligent Design has to offer: "lots of miracles, a handful of equations, and ten straw examples set against thousands of compelling lines of inquiry" (p. 87). But if Intelligent Design has so little to show for itself, how has the movement been so influential? In Chapter 5 ("Science under attack") and Chapter 6 ("The real agenda"), we learn what is really at issue: religion, not science. Shermer considers the beliefs that motivate Intelligent Design's most prominent (and financially weighty) advocates and the problems with trying to 
influence science education through legislation rather than evidence.

Instead of belaboring perceived conflicts between science and religion, Shermer suggests that Christians should embrace science and evolution for its role in revealing the exquisite structure of the natural world and for explaining our own moral sentiments (Chapter 8, "Why Christians and conservatives should accept evolution"). This chapter is the book's least persuasive. Shermer writes that our evolutionary history as a social species accounts for many of the values Christians and conservatives hold most dear: the importance of family, social cohesion, and altruism. But evolution also accounts for between-group competition and violence within and across families. The chapter flirts dangerously with the naturalistic fallacy, the mistake of assuming that "is" implies "ought." Shermer suggests that evolution is hard to accept in part because it is perceived to have dire moral consequences (Chapter 2), but he never takes on the admittedly difficult project of articulating a relationship between descriptive claims (the "is") and prescriptive claims (the "ought").

A more compelling route to reconciling science and religion comes in Shermer's discussions of theology and reasons for belief. He suggests that faith and the experience of God in everyday life can be the basis for "deep and honest theology" (p. 43) and argues that religious challenges to science not only face empirical problems but make for bad theology. "Intelligent Design," he writes, "reduces the deity to a mere engineer, a garage tinkerer" (p. 42). Shermer ultimately endorses the view that science and religion occupy separate worlds, akin to Stephen Jay Gould's "nonoverlapping magisteria" (Gould 2002). But the book also points to the possibility that science can satisfy some of the roles traditionally assigned to religion and faith. Shermer poetically describes the "sensuality of discovery" (p. 161) and emphasizes that science can be a source of spiritual meaning.

The book's title suggests an exploration of the role of evolutionary theory in contemporary science-how it pervades the biological sciences, informs the social sciences, and benefits medicine and public health. But Shermer's take on why Darwin matters is more ambitious. Darwin not only changed our understanding of nature and our place within it but also "launched a new and profound understanding of biology and science that has served future generations" (p. xxii). Shermer writes that Darwin and evolution matter because science matters, and "science matters because it is the preeminent story of our age, an epic saga about who we are, where we came from, and where we are going" (p. 161).

For the most part, Shermer succeeds in discussing religion respectfully and with an insider's sensibility. After considering the arguments for Intelligent Design, for example, he concedes that these arguments can be "reasons to believe if you already believe" (p. 88). But "if you are not a True Believer," he writes, "if you are a skeptic or a Fence Sitter, creationism and Intelligent Design are untenable" (p. 88). If this is right, books like Shermer's will not persuade committed creationists. But for those already sympathetic to evolution, the book provides a more compelling portrait of both sides of the debate than is typical of attacks on creationism.

Shermer succeeds in clear exposition for the novice while offering interesting tidbits for the more informed and provides the kind of systematic exposition that makes the book a valuable introduction or reference for teachers and students. For example, he breaks down arguments into clear steps and offers taxonomies for complex issues, such as the relationship between science and religion (p. 116). The book also includes hefty endnotes and a bibliography for those who want to learn more.

No single book could address every issue relevant to evolution, and Shermer does not try. Those after a thorough exposition of natural selection or the nature of science should look elsewhere, as both topics are addressed clearly but briefly. Shermer takes care to avoid the misconception that evolution is goal-directed, for example, but does little to prevent other common misconceptions. The book is also surprisingly light on psychological evidence or references given the many empirical claims about human cognition (e.g., "lacking a good explanation, the mind defaults to whatever explanation is on the table...", p. 47), a gap in an otherwise well-researched and well-documented work. For example, Shermer suggests that concerns about the consequences of evolution and scientific misunderstanding partially explain resistance to evolution, but the psychological evidence for these claims is remarkably slim (e.g., Brem et al. 2003; Lombrozo et al. 2006, 2008).

What the book lacks in exhaustive coverage it makes up for in intimacy. Shermer is eloquent but conversational, sharing his own experiences to communicate and contextualize broad issues. We learn about his trip to the Galapagos and his tenure with evangelical Christianity as we learn about Darwin (prologue), we learn about the issues in publicly defending evolution through his own debates with creationists (Chapter 4), and we learn about the real open questions and controversies in evolution from the World Summit on Evolution he attended in 2005 (Chapter 9). Given that debates over evolution and evolution education are overwhelmingly motivated by religion rather than science, and by individual beliefs rather than evidence, this human approach may be exactly what is required.

For readers in the first decade of the twenty-first century, Why Darwin Matters matters because it addresses the right issues at the right time. Shermer helps us move beyond the courtroom drama of 2005 to a celebration of Darwin, of evolution, and of science. Whatever the sources of 
resistance to evolution, it is clear that education and enthusiasm will be critical in promoting public understanding, and Shermer's book provides healthy doses of both.

Open Access This article is distributed under the terms of the Creative Commons Attribution Noncommercial License which permits any noncommercial use, distribution, and reproduction in any medium, provided the original author(s) and source are credited.

\section{References}

Behe M. Darwin's black box: the biochemical challenge to evolution. New York: Free Press; 1996.
Brem SK, Ranney M, Schindel JE. The perceived consequences of evolution: college students perceive negative personal and social impact in evolutionary theory. Sci Educ 2003;87:181-206.

Dembski W. No free lunch: why specified complexity cannot be purchased without intelligence. New York: Rowman \& Littlefield; 2002.

Gould SJ. Rock of ages: science and religion in the fullness of life. New York: Ballantine Books; 2002.

Lombrozo T, Shtulman A, Weisberg M. The intelligent design controversy: lessons from psychology and education. Trends Cogn Sci 2006;10:56-7.

Lombrozo T, Thanukos A, Weisberg M. The importance of understanding the nature of science for accepting evolution. Evol Educ Outreach 2008;1:290-8.

Wells J. Icons of evolution: science or myth? Why much of what we teach about evolution is wrong. Washington, D.C.: Regnery; 2000 . 